Abstracta Iranicacta Iranica

Revue bibliographique pour le domaine irano-aryen

Volume 40-41 | 2019

Comptes rendus des publications de 2017-2018

\title{
Hamidreza P. Zanous, Juping Yang. “Arsacid Cities in the Hanshu and Houhanshu"
}

\section{Leonardo Gregoratti}

\section{(2) OpenEdition \\ 12 Journals}

\section{Electronic version}

URL: http://journals.openedition.org/abstractairanica/49770

DOI: 10.4000/abstractairanica.49770

ISBN: 1961-960X

ISSN: 1961-960X

Publisher:

CNRS (UMR 7528 Mondes iraniens et indiens), Éditions de l'IFRI

Electronic reference

Leonardo Gregoratti, "Hamidreza P. Zanous, Juping Yang. "Arsacid Cities in the Hanshu and

Houhanshu"', Abstracta Iranica [Online], Volume 40-41 | 2019, document 45, Online since 30 October 2019, connection on 18 April 2021. URL: http://journals.openedition.org/abstractairanica/49770 ; DOI: https://doi.org/10.4000/abstractairanica.49770

This text was automatically generated on 18 April 2021.

Tous droits réservés 


\title{
Hamidreza P. Zanous, Juping Yang. "Arsacid Cities in the Hanshu and Houhanshu"
}

\author{
Leonardo Gregoratti
}

\section{REFERENCES}

Hamidreza P. Zanous, Juping Yang. "Arsacid Cities in the Hanshu and Houhanshu”, Iran and the Caucasus, 22 (2018), p. 123-138

1 The authors of this paper focus on the precious information from the Chinese sources, and in particular the Annals of the Former Han and the Annals of the Later Han, can provide about the Arsacid Empire. The main problem concerning these sources is the correct identification of the place names mentioned with actual places within or outside the Parthia. The Parthian empire is normally called Anxi by Chinese chroniclers, probably a transcription of the kings' name Arsakes. It designates Parthia proper and the country where the most ancient Arsacid cities lay: Nisa (Fandou = Parthava), Hedu (Hecatompylos) and Mulu (Merv). The semi-independent kingdom of Wuyishali is identified with the area of the Indo-Parthian kingdom, later occupied by the Kushans. The geographical identity of places further west like Aman is still discussed, while Sabin seem s to refer to Susa and Yuluo to Characene, also called Tiaozhi in the later Han Annals. 


\section{AUTHORS}

\section{LEONARDO GREGORATTI}

Durham University 